\title{
Effect of traumatic acid on antioxidant activity in Chlorella vulgaris (Chlorophyceae)
}

\author{
Anna Pietryczuk • Romuald Czerpak
}

Received: 17 December 2010/Accepted: 18 May 2011/Published online: 3 June 2011

(C) The Author(s) 2011. This article is published with open access at Springerlink.com

\begin{abstract}
The present study was undertaken to test the influence of exogenously applied traumatic acid (TA) upon the activity of several antioxidant enzymes as well as lipid and protein peroxidation in green algae Chlorella vulgaris. Treatment with TA in concentration range of $10^{-6}-10^{-5} \mathrm{M}$ resulted in an increase of antioxidant enzyme (sodium dismutase, catalase, ascorbate peroxidase, NADH peroxidase, glutathione reductase) activity. Moreover, TA suppressed lipid peroxidation and oxidative destruction of proteins belonging to the $\mathrm{SH}$ groups. This data suggest that TA plays an important role in the metabolism of $C$. vulgaris and probably in its high ability to adapt to various environmental stress factors.
\end{abstract}

Keywords Traumatic acid Chlorella vulgaris - Sodium dismutase $\cdot$ Catalase $\cdot$ Ascorbate peroxidase $\cdot$ NADH peroxidase - Glutathione reductase - Lipid peroxidation · Protein SH group

\section{Introduction}

Typical phytohormones are not the only compounds which participate in the control of plant development and growth. These processes also involve other small-molecule chemical compounds. An example of such a compound is plant wound hormone traumatic acid, (TA, trans-2-dodeceno1.12-dicarboxylic acid). The first effect of TA in plants was found to be an intense stimulation of cell division within

A. Pietryczuk $(\bowtie) \cdot$ R. Czerpak

Institute of Biology, Department of Plant Biochemistry

and Toxicology, University of Białystok, Świerkowa 20B,

15-950 Białystok, Poland

e-mail: annapiet@uwb.edu.pl a wounded area and the formation of callus tissue (Zimmerman and Coudron 1979). Precursors of traumatic acid are 18-carbon non-saturated fatty acids: linolic and linolenic acids, which are released from membrane lipid fractions as a result of phospholipases $\mathrm{A}_{2}$ (EC 3.1.1.4) and $\mathrm{D}$ (EC 3.1.4.4) It is also known that these phospholipases are mainly activated as a reaction to an injury of the plant (León et al. 2001; Grekchin 2002). However, research carried out over the past several years has shown that the synthesis of traumatic acid is induced not only through injury, but also by other environmental stress factors such as high and low temperature or UV radiation or osmotic shock (Siedow 1991; Howe and Schilmiller 2002).

So far very few analyses of physiological and metabolic effects of traumatic acid and its derivatives on plants have been carried out. Our previous research has shown that TA triggers an increase in cell number (by 77\%), as well as cell content of primary metabolites: monosaccharides by $111 \%$, chlorophyll $a$ by $126 \%$, chlorophyll $b$ by $45 \%$, carotenoids by $65 \%$ and cell proteins by $37 \%$, of Chlorella vulgaris (C. vulgaris) in comparison with control, especially at concentrations of $10^{-6}-10^{-5} \mathrm{M}$ on the $3 \mathrm{rd}$ day of culture. It has also been pointed out that new proteins (unidentified in control) with molecular masses of 13-103 kDa appear in algae cells treated with exogenous TA (Pietryczuk et al. 2008). Experimentally there are also reasons to believe that TA, most probably acting in synergy with other phytohormones, particularly jasmonic acid (JA) and abscisic acid (ABA), plays an important role in inducing physiological and metabolic responses not only to injury but also to many other environmental stress factors (Sivasankar et al. 2000). From the data available in literature it also appears that TA takes part in plant response to different stress factors, accompanied by the production of large amounts of ROS (reactive oxygen species). It is additionally known that ROS 
and antioxidant enzymes take part in the regulation of plant growth and metabolism and play a role of a secondary transmitter for many hormones, including jasmonic acid which, like TA, is a derivative of polyunsaturated fatty acids (Kwak et al. 2006). Hence, the aim of this research became to gauge the influence of TA on select antioxidant enzymes which probably take part in TA signaling on the molecular level. With regard to the sparse scientific analyses which has been carried out, it needs to be assumed that TA is a compound which actively participates in controlling many biochemical and physiological processes in plants, particularly those related to the environmental stress response mechanisms. So far, we still have not found exactly which processes are controlled by TA.

In plant biochemistry and physiology the most convenient experimental material is the unicellular alga $C$. vulgaris since hormonal perception and biological response take place within a single cell. Additionally, green algae are evolutionally the nearest to vascular plants and their metabolism is most closely related to that of higher plants. Understanding the mechanisms of the workings of TA in C. vulgaris would be a significant step to the recognition of the role of this compound among higher plants.

With reference to the abovementioned scientific reports, the primary aim of the work was to determine the influence of TA on the antioxidant processes required for neutralisation of free radicals produced not only as an effect of various stress factors that induce TA accumulation in plants, but also in physiological conditions during normal biochemical oxidoreductive processes such as respiration or photosynthesis. We tested the hypothesis that TA-induced changes in growth and metabolism may be connected with its influence on the oxidative response. For this purpose the influence of TA on the activity of the primary antioxidant enzymes: glutathione reductase (GR), superoxide dysmutase (SOD), NADHdependent peroxidase, ascorbate peroxidase (APX) and catalase, has been analysed in a previously established optimal scope of concentrations (Pietryczuk et al. 2008). The degree of protein modification has also been analysed regarding their content of the SH groups (reduced thiol group) and lipids peroxidation, based on the content of malonic dialdehyde (MDA). An increase of activity of antioxidant enzymes through the influence of TA would indicate high capabilities of this phytohormone to participate in the plants' response to oxidative stress.

\section{Materials and methods}

Plant material and growth conditions

Axenic cultures of the green algae $C$. vulgaris Beijerinck (Chlorophyceae) were obtained from the Department of
Plant Biochemistry and Toxicology at the University of Białystok. C. vulgaris cells were cultivated for 7 days under controlled conditions at $25 \pm 0.5^{\circ} \mathrm{C}$. Illumination was supplied during a 16 -h photoperiod ( 8 -h dark period) by a bank of fluorescent lights yielding a photon flux density of 50 $\mu \mathrm{mol} \mathrm{m} \mathrm{m}^{-2} \mathrm{~s}^{-1}$ of photosynthetically active radiation (PAR) at tube surface. PAR was measured with a FF-01 (SOMOPAN, Poland) phytophotometre. Permanent synchronous growth was established according to the Pirson and Lorenzen method (1966). Culture medium used was a modified Knop's medium with the following components: $0.5 \mathrm{~g} \mathrm{KNO}_{3}, 0.5 \mathrm{~g}$ $\mathrm{Ca}\left(\mathrm{NO}_{3}\right)_{2} \cdot 4 \mathrm{H}_{2} \mathrm{O}, 0.2 \mathrm{~g} \quad \mathrm{KH}_{2} \mathrm{PO}_{4}, 0.15 \mathrm{~g} \quad \mathrm{MgSO}_{4} \cdot 7 \mathrm{H}_{2} \mathrm{O}$, $0.01 \mathrm{~g} \mathrm{FeCl}_{3} \cdot 6 \mathrm{H}_{2} \mathrm{O}, 0.003 \mathrm{~g} \mathrm{H}_{3} \mathrm{BO}_{3}, 0.002 \mathrm{~g} \mathrm{MnCl}_{2} \cdot 4 \mathrm{H}_{2} \mathrm{O}$, $0.0003 \mathrm{~g} \quad \mathrm{NH}_{4} \mathrm{VO}_{3}, \quad 0.0002 \mathrm{~g} \quad \mathrm{ZnSO}_{4} \cdot 7 \mathrm{H}_{2} \mathrm{O}, \quad 0.0001 \mathrm{~g}$ $\left(\mathrm{NH}_{4}\right)_{6} \mathrm{Mo}_{7} \mathrm{O}_{24} \cdot 7 \mathrm{H}_{2} \mathrm{O}$ in 11 of distilled water. The culture medium and glassware were sterilized by autoclaving at $125^{\circ} \mathrm{C}$ for $25 \mathrm{~min}$. The $\mathrm{pH}$ of the medium was adjusted to 6.8 with $1 \mathrm{M} \mathrm{NaOH}$. C. vulgaris was cultured in Erlenmeyer flasks $(500 \mathrm{ml})$ containing $250 \mathrm{ml}$ of medium and shaken at $150 \mathrm{rpm}$ in a rotary shaker. TA was obtained from Sigma Chemical Co. (USA). TA dissolved in $0.1 \mathrm{M} \mathrm{NaOH}$ was applied at two concentrations: $10^{-5}$ and $10^{-6}$ M. C. vulgaris cultures were treated with appropriate concentrations of TA on the day of culture creation (day 0). An equal amount of $0.1 \mathrm{M} \mathrm{NaOH}$ was added to the control. Concentrations of TA used to ascertain antioxidant enzyme activity were calculated on the basis of our preliminary research. The influence of TA in concentrations ranging from $10^{-6}$ to $10^{-3} \mathrm{M}$ on growth (expressed in number of cells) and on the content of basic metabolites within the cells of the algae has been researched. As a result of treatment of $C$. vulgaris with TA at $10^{-6}$ $10^{-5} \mathrm{M}$ the greatest increase (in comparison to control) in cell number, proteins, monosaccharides and photosynthetic pigments has been observed (Pietryczuk et al. 2008). These concentrations therefore have been deemed as the most active. Cultures were replicated five times. Algal samples for determination of antioxidant enzyme activity were collected on day $0,1,3,5$ and 7 of cultivation. The initial cell density was about $10.6 \times 10^{5}$ cells per $\mathrm{ml}$ in all flasks.

\section{Assay of enzyme activities}

To extract ascorbate peroxidase, NADH peroxidase and catalase, fresh weight of $C$. vulgaris was passed through filter paper under pressure and homogenized using liquid nitrogen and subsequently a lysis buffer containing $0.1 \mathrm{M}$ sodium phosphate buffer (pH 6.0), $0.1 \mathrm{mM}$ EDTA and $1 \%$ PVP. The homogenate was centrifuged at $12000 \times g$ for $20 \mathrm{~min}$ and the resulting supernatant was used for the determination of enzyme activity. The entire extraction procedure was carried out at $4{ }^{\circ} \mathrm{C}$.

Total ascorbate peroxidase (EC 1.11.1.11) was determined according to the method described by Nakano and 
Asada (1981). The reaction mixture consisted of $0.05 \mathrm{M}$ phosphate buffer ( $\mathrm{pH} 7.0)(1.8 \mathrm{ml}), 5 \mathrm{mM}$ sodium ascorbate (20 $\mu \mathrm{l}), 0.1 \mathrm{mM} \mathrm{H}_{2} \mathrm{O}_{2}(100 \mu \mathrm{l})$, and supernatant $(100 \mu \mathrm{l})$. Total ascorbate peroxidase activity was determined as the decrease in absorbance of ascorbate at $290 \mathrm{~nm}$ and calculated using a molar extension coefficient $\mathrm{e}=2.8 \mathrm{mM}^{-1}$ $\mathrm{cm}^{-1}$. The enzyme activity (U) was calculated as the amount of the enzyme that oxidizes $1 \mu \mathrm{mol}$ ascorbate consumed $/ \mathrm{mg}$ soluble protein per minute at $30^{\circ} \mathrm{C}$.

NADH peroxidase (EC 1.11.1.1) activity was determined according to Ishida et al. (1987). The reaction mixture consisted of $50 \mathrm{mM}$ phosphate buffer ( $\mathrm{pH}$ 6.0) $(1.8 \mathrm{ml})$ and $0.2 \mathrm{mM} \mathrm{NADH}(100 \mu \mathrm{l})$. The reaction was initiated by adding the enzymatic extract $(100 \mu \mathrm{l})$ and lasted for up to $5 \mathrm{~min}$. The peroxidase activator of $5 \mathrm{nM}$ $\mathrm{MnCl}_{2}(12.5 \mathrm{ml})$ were used. The activity was calculated with a molar extinction coefficient $\mathrm{e}=6.3 \mathrm{mM}^{-1} \mathrm{~cm}^{-1}$ for NADH. One unit of NADH peroxidase activity (U) was assumed to be the amount of the enzyme that oxidizes $1 \mu \mathrm{mol} \mathrm{NADH} / \mathrm{mg}$ soluble protein per minute at $30^{\circ} \mathrm{C}$.

Catalase (EC 1.11.1.6) activity was determined following Aeby (1984). The rate of $\mathrm{H}_{2} \mathrm{O}_{2}$ decomposition at $240 \mathrm{~nm}$ was measured spectrophotometrically and calculated using a molar extension coefficient $\mathrm{e}=45.2 \mathrm{mM}^{-1} \mathrm{~cm}^{-1}$. The reaction mixture consisted of $0.05 \mathrm{M}$ phosphate buffer $(\mathrm{pH}$ 7.0) $(2 \mathrm{ml}), 0.1 \mathrm{mM} \mathrm{H}_{2} \mathrm{O}_{2}(1 \mathrm{ml})$, and supernatant (100 $\left.\mu \mathrm{l}\right)$. One unit of catalase activity (U) was assumed to be the amount of enzyme that decomposed $1 \mu \mathrm{mol} \mathrm{H}_{2} \mathrm{O}_{2} / \mathrm{mg}$ soluble protein per minute at $30^{\circ} \mathrm{C}$.

For the extraction of glutathione reductase, fresh weight of $C$. vulgaris was passed through filter paper under pressure and homogenized using liquid nitrogen and subsequently a lysis buffer containing $0.02 \mathrm{M}$ phosphate buffer ( $\mathrm{pH}$ 7.0). The homogenate was centrifuged at $12000 \times g$ for $10 \mathrm{~min}$ and the resulting supernatant was used to determine of enzyme activity. The entire extraction procedure was carried out at $4^{\circ} \mathrm{C}$. Glutathione reductase (EC 1.6.4.2) activity was determined according to Foyer and Halliwel (1976). The reaction mixture consisted of $0.25 \mathrm{M} \mathrm{KCl}$ in $0.02 \mathrm{M}$ phosphate buffer $(\mathrm{pH}=7.0)(1 \mathrm{ml}), 7 \mathrm{mM}$ glutathione disulfide $(0.25 \mathrm{ml})$ and enzymatic extract $(0.1 \mathrm{ml})$. The reaction was initiated by adding $0.7 \mathrm{mM} \mathrm{NADPH}$ $(0.5 \mathrm{ml})$. NADPH concentration declined in the optical density at $340 \mathrm{~nm}$, and activity was calculated using the extinction coefficient $\mathrm{e}=62.2 \mathrm{mM}^{-1} \mathrm{~cm}^{-1}$ for NADPH. One unit of glutathione reductase was defined as the amount of enzymes needed to break down $1 \mu \mathrm{mol}$ of NADPH/mg soluble protein per minute.

For the extraction of sodium dismutase, fresh weight of $C$. vulgaris was passed through filter paper under pressure and homogenized using liquid nitrogen and subsequently a lysis buffer containing $0.1 \mathrm{M}$ phosphate buffer ( $\mathrm{pH} 7.8$ ), $3 \mathrm{mM}$ $\mathrm{MgSO}_{4}, 1 \mathrm{mM}$ dithiotreitol (DTT) and $3 \mathrm{mM}$ EDTA. The homogenate was centrifuged at $12000 \times g$ for $10 \mathrm{~min}$ and the resulting supernatant was used to determine enzyme activity. Sodium dismutase (EC 1.15.1.1) activity was measured based on the inhibition of the photochemical reduction of nitroblue tetrazolium (NBT) according to Beauchamp and Fridovich (1971). The reaction mixture consisted of $0.1 \mathrm{M}$ phosphate buffer $(\mathrm{pH}=7.8)(2.2 \mathrm{ml}), 0.156 \mathrm{mM}$ riboflavin $(0.25 \mathrm{ml}), 0.156 \mathrm{mM}$ methionine $(0.25 \mathrm{ml}), 0.756 \mathrm{mM}$ $\operatorname{NBT}(0.25 \mathrm{ml})$ and enzymatic extract $(50 \mu \mathrm{l})$. Samples were incubated for $20 \mathrm{~min}$ in room temperature. The absorbance of the extracts was measured spectrophotometrically at $560 \mathrm{~nm}$. One unit of the SOD activity was defined as the enzyme concentration required to inhibit the reduction of NBT by $50 \%$.

\section{Determination of lipid peroxidation}

Lipid peroxidation was determined by measuring malonic dialdehyde (MDA) concentration, using the thiobarbituric acid (TBA, Sigma) method described by Heath and Packer (1968). Fresh weight of $C$. vulgaris was passed through filter paper under pressure, homogenized in $0.1 \%$ trichloroacetic acid (TCA) and centrifuged at $12000 \times g$ for $10 \mathrm{~min}$. The supernatant was used for MDA content determination. MDA absorption was measured spectrophotometrically at $532 \mathrm{~nm}$ and MDA concentration was calculated using an extinction coefficient $\mathrm{e}=156 \mathrm{mM}^{-1} \mathrm{~cm}^{-1}$. The concentration of MDA was expressed as nmol $\mathrm{mg}^{-1}$ of the protein.

\section{Determination of $-\mathrm{SH}$ groups}

Fresh weight of $C$. vulgaris was passed through filter paper under pressure and homogenized in $10 \mathrm{mM}$ potassium-phosphate buffer $(\mathrm{pH}$ 8.0) and centrifuged at $12000 \times g$ for $10 \mathrm{~min}$. The supernatant was used to determine the content of $\mathrm{SH}$ groups. In order to ascertain the content of SH groups the samples were mixed with Ellman's reagent $\left(5,5^{\prime}\right.$,-dithiobis-2-nitrobenzoic acid, DTNB, Sigma) in $10 \mathrm{mM}$ potassium-phosphate buffer ( $\mathrm{pH} 8.0$ ) (Rice-Evans et al. 1991). Absorbance of the products of DTNB reaction with $\mathrm{SH}$ groups was measured at $412 \mathrm{~nm}$. The $\mathrm{SH}$ group concentration was calculated using an extinction coefficient $\mathrm{e}=13.6 \mathrm{mM}^{-1} \mathrm{~cm}^{-1}$. The concentration of $\mathrm{SH}$ groups was expressed as $\mathrm{nmol} \mathrm{mg}^{-1}$ of the protein.

Cell protein concentrations were measured according to Lowry's method (1951), using bovine serum albumin as a calibration standard.

All enzyme activity was measured using a Shimadzu UV-Vis 1201 spectrophotometer.

Each treatment was repeated five times and each experiment was carried out at least twice at different times. 
Data was expressed as a mean $\pm \mathrm{SE}$. A minitab statistical package was used to carry out a one-way ANOVA. Student's $t$-test was used to estimate the difference between means. Differences where $P<0.05$ were considered statistically significant.

\section{Results}

The greatest influence of TA concentrations at $10^{-6}$ and $10^{-5} \mathrm{M}$ on the activity of selected antioxidant enzymes and on lipid and protein peroxidation was examined. Results have been displayed on illustrations 1-7

The conducted research has pointed out that TA facilitates an increase of ascorbate peroxidase (APX) (Fig. 1) activity. As a response to exogenous treatment with $10^{-6}$ and $10^{-5} \mathrm{M}$ TA, the increase of the analysed enzyme in the algae cells is highest on the $3 \mathrm{rd}$ day of the experiment. It is from 45.7 to $50 \%$ higher when compared to the control.

Similar results have been obtained in case of the NADHdependent peroxidase (Fig. 2). Reacting to TA, the algae cells demonstrate the highest level of this enzyme activity on the 3rd day of culture, when it increases by $56.8-64.9 \%$ in comparison to control.

Catalase (CAT) is also an important enzyme that participates in antioxidant processes of plants. The highest increase of CAT in algae cells treated with $10^{-6}$ and $10^{-5} \mathrm{M}$ TA, by 56.5 up to $62.3 \%$ in comparison to the control, has been recorded on the 3rd day of the experiment (Fig. 3).

Another enzyme whose activity has been analysed was glutathione reductase (GR). NADPH oxidation catalysed by GR, increases in the algae cells by $51.3-58.2 \%$ under the influence of TA on the 3rd day of the experiment in comparison to the control culture (Fig. 4).

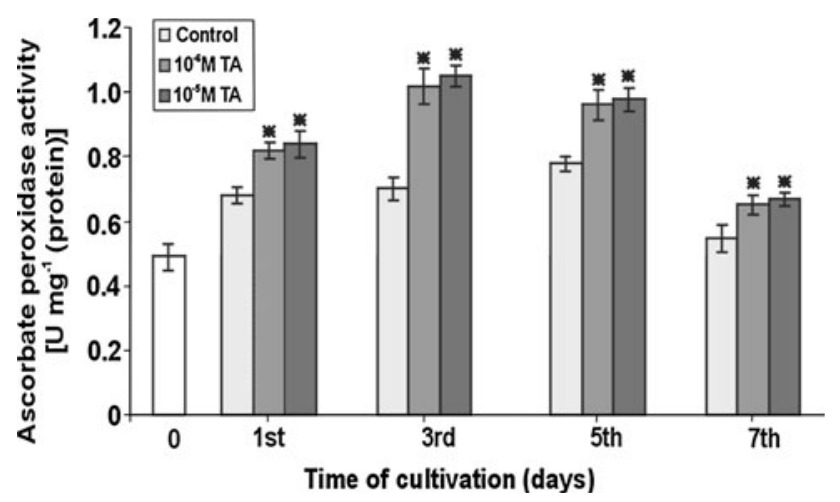

Fig. 1 The effect of $10^{-6}-10^{-5} \mathrm{M}$ traumatic acid on the ascorbate peroxidase activity in Chlorella vulgaris. Data are the means of five independent experiments $\pm \mathrm{SE},(*$ result significantly different in comparison to the control)

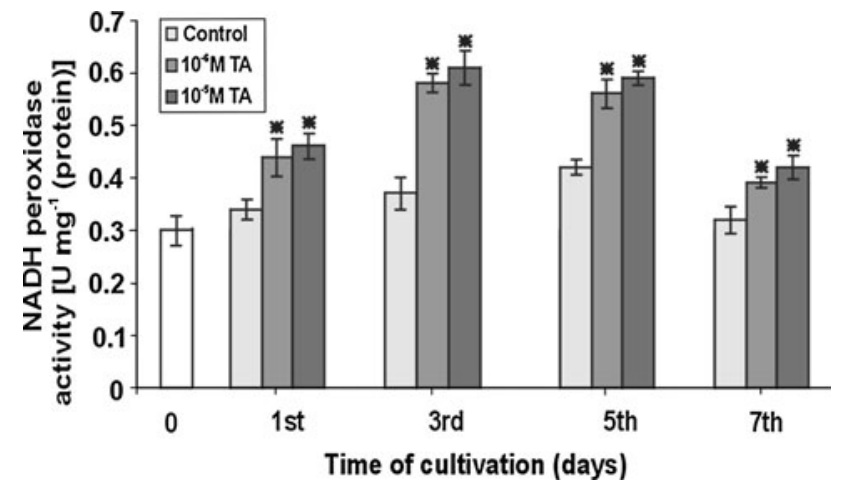

Fig. 2 The effect of $10^{-6}-10^{-5} \mathrm{M}$ traumatic acid on the NADH peroxidase activity in Chlorella vulgaris. Data are the means of five independent experiments \pm SE. (* result significantly different in comparison to the control)

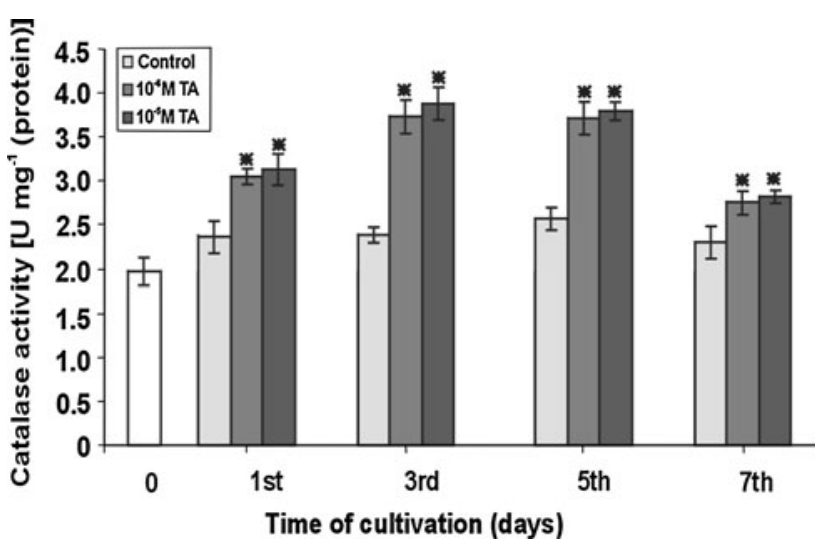

Fig. 3 The effect of $10^{-6}-10^{-5} \mathrm{M}$ traumatic acid on the catalase activity in Chlorella vulgaris. Data are the means of five independent experiments $\pm \mathrm{SE}$, (* result significantly different in comparison to the control)

Similarly, as in case of the antioxidant enzymes described so far, the activity of superoxide dismutase (SOD) significantly increases as a response to treatment with exogenous TA (Fig. 5). The algae cells treated with TA demonstrate the highest increase of SOD activity on the 3rd day of culture, by 60.7 up to $69.4 \%$, as compared with the control sample.

Additionally, the influence of TA on lipid peroxidation has been analysed on the basis of malonic dialdehyde (MDA) content-the main marker of lipid peroxidation. Under the influence of TA in the concentration range between $10^{-6}$ and $10^{-5} \mathrm{M}$, a significant drop of MDA was found in C. vulgaris cells, reaching $30-41 \%$ in relation to control, on the 3rd and the 5th day of culture (Fig. 6).

The inhibition of the oxidation of cell proteins belonging to the SH group was also observed in algae cells growing with the presence of TA (Fig. 7) In response of exogenously added TA, the content of SH group proteins in 


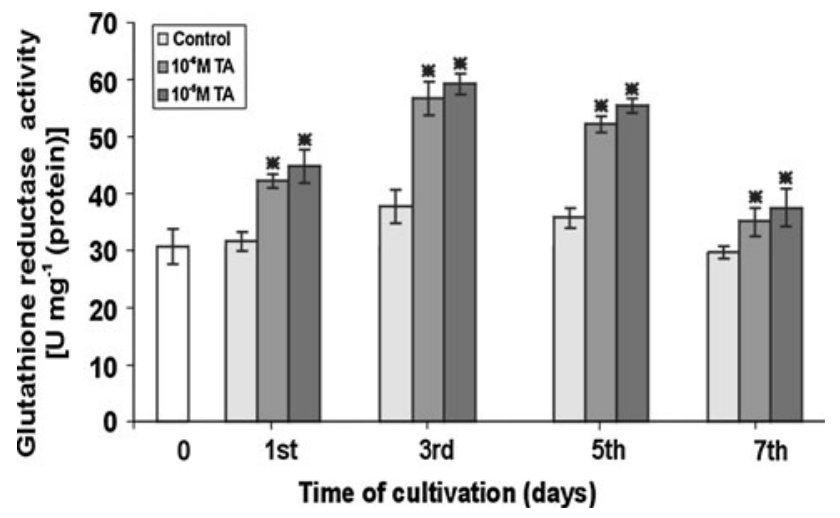

Fig. 4 The effect of $10^{-6}-10^{-5} \mathrm{M}$ traumatic acid on the glutathione reductase activity in Chlorella vulgaris. Data are the means of five independent experiments $\pm \mathrm{SE}$, (* result significantly different in comparison to the control)

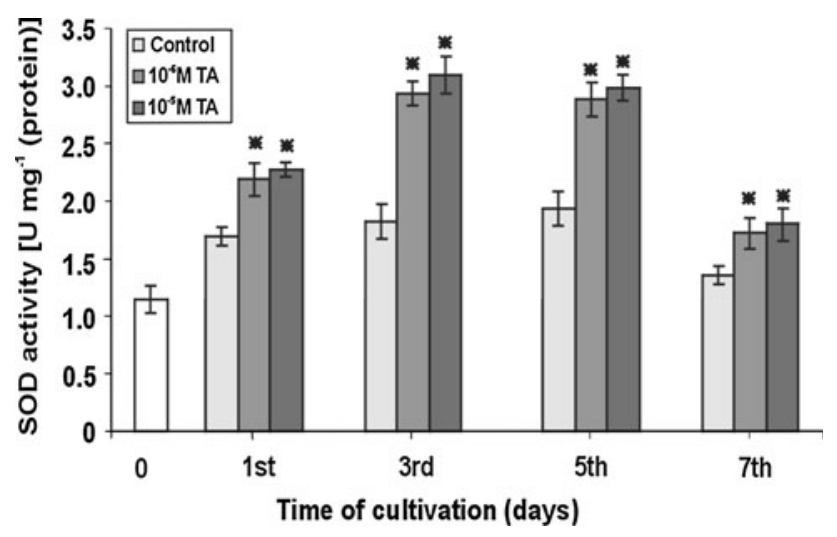

Fig. 5 The effect of $10^{-6}-10^{-5} \mathrm{M}$ traumatic acid on the sodium dismutase activity in Chlorella vulgaris. Data are the means of five independent experiments $\pm \mathrm{SE}$, (* result significantly different in comparison to the control)

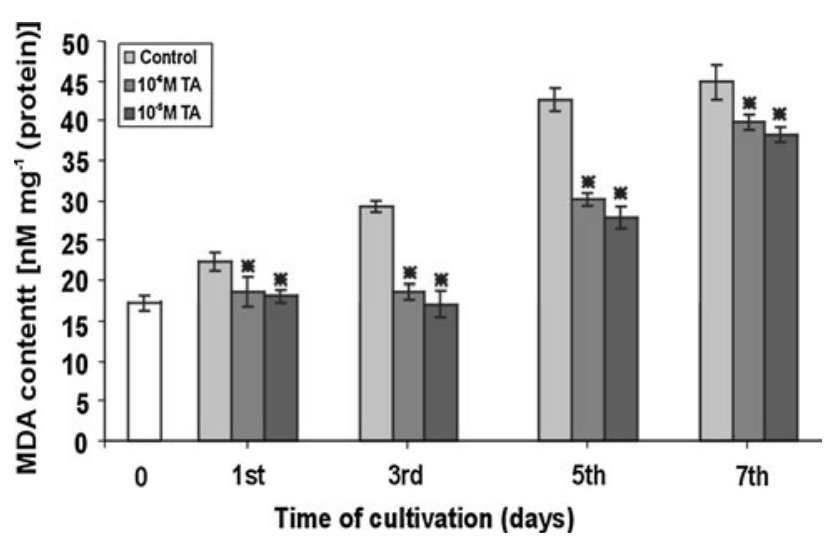

Fig. 6 The effect of $10^{-6}-10^{-5} \mathrm{M}$ traumatic acid on the lipid peroxidation (expressed by MDA content) in Chlorella vulgaris. Data are the means of five independent experiments $\pm \mathrm{SE},\left(^{*}\right.$ result significantly different in comparison to the control)
C. vulgaris increases the most by $65.5-68.6 \%$ on the 3 rd day of the experiment in comparison to the control culture. TA activity decreases along with the progression of time of culture.

\section{Discussion}

In living cells ROS (reactive oxygen species) are produced as side products or intermediates of oxygen metabolism as a result of correct metabolic transformations during biochemical oxidoreductive processes such as: respiration, light phase of photosynthesis and reactions catalysed by oxidoreductases localised in peroxisomes and glycoxysomes, as well as in pathological situations caused by unfavourable environmental conditions. In physiological conditions these processes are precisely controlled by the organism, as a result of the enzymatic and non-enzymatic defensive mechanisms.

Plants have efficiently functioning defensive systems against reactive oxygen forms. They consist of enzymes neutralising ROS, most important of which are: superoxide dismutases (SOD), catalase (CAT), ascorbate peroxidase (APX), NADH-dependent peroxidase as well as reductase and glutathione peroxidase.

Sparse analyses indicate that TA is accumulated in plant tissues as a result of stress factors such as high and low temperature, drought and injury, as well as the attack of pathogens which generate high amounts of ROS. Therefore, it seems probable that TA participates in activation of the immunity of plants against various types of environmental stress by intensifying the activity of antioxidant enzymes. Our research has shown that in fact TA demonstrates antioxidant activity. In C. vulgaris cells treated with

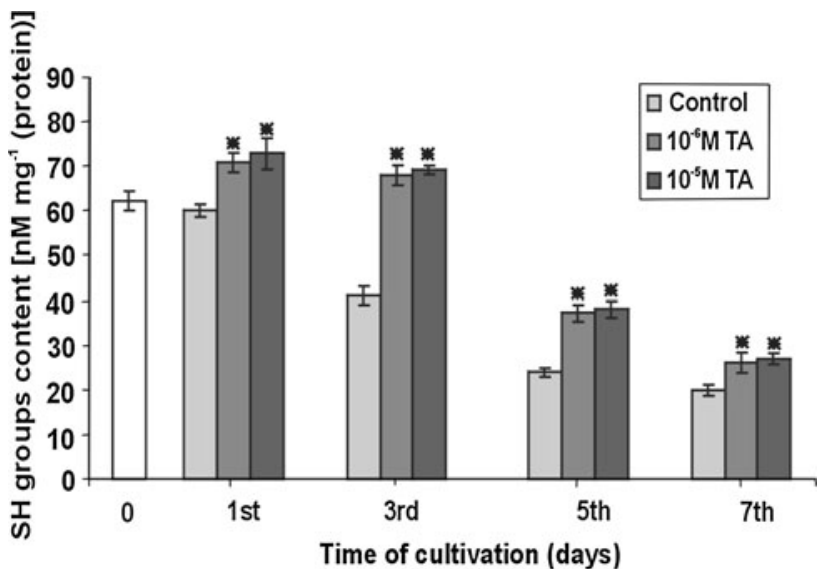

Fig. 7 The effect of $10^{-6}-10^{-5} \mathrm{M}$ traumatic acid on the SH groups content in Chlorella vulgaris. Data are the means of five independent experiments $\pm \mathrm{SE}$, (* result significantly different in comparison to the control) 
this hormone a significant increase of activity of antioxidant enzymes has been observed as compared with control cultures, even under normal physiological conditions, with correct course of metabolic processes. Additionally TA most powerfully stimulates activity of superoxide dismutase which increases by $61-69 \%$ in relation to the control culture.

Bowler et al. (1992) suggest that derivatives of nonsaturated fatty acids, in all probability TA as well, can assume the role of transmitters of signals to the nucleus and can induce the expression of SOD genes. Furthermore, stimulation of SOD activity can be positively correlated with the increase of GR activity. It has been pointed out that for certain plant species, for instance tobacco, increased concentration of reduced glutathione (product of reaction catalysed by GR) induces an increase of mRNA content of cytosolic CuZnSOD (Żuchowski 1999). It cannot be excluded, though, that a similar dependence occurs in C. vulgaris as well. It is also known that ROS as well as antioxidant enzymes, particularly plant peroxidases (APX and NADH-dependent), actively participate in the regulation and modification of various physiological and metabolic processes, both at the cell level and in reference to the entire multi-cellular plant. They play an active part, among others, in controlling such processes as: cell divisions, programmed cell death (PCD), regulation of stomata movements, morphogenesis, gravitropism, growth and development of roots, cell wall metabolism, ageing, auxin catabolism and hormonal signalling. Numerous publications state that ROS, and especially $\mathrm{H}_{2} \mathrm{O}_{2}$, fulfill the role of secondary transmitters in hormone signaling. This includes JA, which, similarly to TA, is a derivative of polyunsaturated fatty acids in plant tissue. ROS induces also gene expression and synthesis of different proteins relating to hormones. It has been additionally shown that some phytohormones, including JA, can regulate the synthesis and activity of antioxidant enzymes which take part in the growth and development process of plants. Moreover, Carpin and others (2001) suggested that the epidermis of zucchini (Cucurbita pepo) has strong peroxidase activity which stimulates polymerization of phenolics. Peroxidases are also known to participate in lignin and suberin formation in the cell walls and in the establishment of covalent bonds between hydroxycinnamate ester moieties or flavonoids associated with pectins or hemicelluloses as well as in the catabolism of auxins (Maksymiec and Krupa 2002; Pasternak et al. 2002; Kawano 2003; Mittler et al. 2004; Gapper and Dolan 2006; Kwak et al. 2006; Haluškova et al. 2010). Therefore, it can be supposed that in $C$. vulgaris the stimulation of antioxidant enzymes by $\mathrm{TA}$ is related to the control of growth and numerous metabolic processes which leading to the induction of cell division and, as we pointed out in the previous study, to the intensification of biosynthesis in them, as well as the accumulation of primary metabolites. Moreover, traumatic acid, especially at concentrations of $10^{-6}-10^{-5} \mathrm{M}$, on the 3rd day of culture caused more than doubling of algae cell growth (by 77\% in comparison with control) (Pietryczuk et al. 2008). This is closely related to the increase of antioxidant enzyme activity, which has also been observed to be the most active, in comparison to control, on the 3rd day of the experiment. Data obtained from literature states that phytohormones can regulate the activity of antioxidant enzymes which, especially plant peroxideses, take part in the growth and development processes of plants (Kwak et al. 2006). The aim of our work was therefore to check if the induction of cell division and other metabolic processes could be connected with an increase in the activity of antioxidant enzymes. Additionally, stimulation of activity of CAT, APX and NADH-dependent peroxidase has been recognised in W. arrhiza (Piotrowska et al. 2010) and CAT, APX and GPX (guaiacol peroxidase) in a sunflower (Helianthus annuus) (Parra-Lobato et al. 2009) grown in physiological conditions with the influence of another derivative of polyunsaturated fatty acids-JA. It is known from literature (May et al. 1998; Ogawa 2005) that reduced glutathione (GSH) also participates in the stimulation of the immune system of plants to act against pathogen attacks. Our research has shown that TA activates GR, while in older literature (Lee et al. 1998; Howe and Schilmiller 2002; Szczegielniak 2007) it can be found that TA, in fact, participates in the plant's reaction to pathogen attacks.

An increase in the activity of antioxidant enzymes in a cell results in the inhibition of the process of oxidation of membrane phospholipids and thiol group proteins. This is the reason that the content of malonic dialdehyde (MDA) - the marker of peroxidation of lipids, and the reduction of thiol group proteins in the cells of $C$. vulgaris treated with optimal TA concentrations, was determined. The results obtained indicate that TA contributes to the reduction of intensity of oxidation of membrane phospholipids and has a positive influence on proteins that contain sulfhydryl groups. During the experiment, along with the passage of time, the MDA content increased in the control cultures of $C$. vulgaris. This is probably related to the process of cell ageing and the intensification of free radical reactions.

Glutathione reductase (GR) is the major cell enzyme that maintains proper relation between reduced glutathione (GSH) and its oxidised form-glutathione disulphide (GSSG). Our research implies that TA stimulates GR 
activity, which is probably followed by an increase of GSH concentration in C. vulgaris. GSH is responsible, among others, for the protection of cysteine residues against oxidation and for the removal of harmful products of lipid peroxidation. Most recent studies (Szalai et al. 2009) indicate that in plants, at optimal conditions of growth, which are not exposed to any stress factors, there occurs a high relation of GSH to GSSG, which induces the formation of a reductive environment in cells, favourable for maintaining proper biological structure and activity of cell proteins. In our research shown in this paper it has been pointed out that the decrease of MDA concentration and the increase of the content of the proteins belonging to the $\mathrm{SH}$ groups is induced by TA and correlates with an increase of activity of the enzyme GR. It has also been indicated experimentally that JA controls the transcription of GSH1 and GSH2 genes, which encode GSH synthesis, and those genes whose products are engaged in GSH metabolism (Foyer and Noctor 2005; Sasaki-Sekimoto et al. 2005). Data from literature and the results of our research imply that GSH metabolism is most probably controlled by TA as well.

To sum up, it should be stated that TA has a positive influence on the primary biochemical parameters related to the plants' adaptation to oxidative stress. Above all, it intensifies activity of antioxidant enzymes and inhibits the processes of oxidative degradation of lipids and proteins caused by ROS, even in physiologically optimal environmental conditions. The results obtained can indicate the high possibility that TA participates in plants' response to oxidative stress. Furthermore, it seems that the mechanisms of molecular action of TA on the cellular level, which control growth and metabolism of plants, are related to the activation of antioxidant enzymes which actively participate in the control and modification of various physiological and metabolic processes, both at the cell level and in reference to the entire multi-cellular plant.

Open Access This article is distributed under the terms of the Creative Commons Attribution Noncommercial License which permits any noncommercial use, distribution, and reproduction in any medium, provided the original author(s) and source are credited.

\section{References}

Aeby H (1984) Catalase in vitro. Methods Enzymol 105:125-212

Beauchamp C, Fridovich I (1971) Superoxide dismutase improved assays and an assay applicable to acrylamide gels. Anal Biochem 444:276-287

Bowler C, Van Montague M, Inez D (1992) Superoxide dismutase and stress tolerance. Annu Rev Plant Physiol Plant Mol Biol 43:83-116

Carpin S, Crèvecoeur M, de Meyer M, Simon P, Greppin H, Claude P (2001) Identification of a Ca2?-pectate binding site on an apoplastic peroxidase. Plant Cell 13:511-520
Foyer CH, Halliwel B (1976) The presence of glutathione and glutathione reductase in chloroplast: a proposed role in ascorbic acid metabolism. Planta 133:21-25

Foyer CH, Noctor G (2005) Oxidant and antyoxidant signalling in plants: a re-evaluation of the concept of oxidative stress in a physiological context. Plant Cell Environ 28:1056-1071

Gapper C, Dolan L (2006) Control of plant development by reactive oxygen species. Plant Physiol 141:341-345

Grekchin AN (2002) Hydroperoxide lyase and divinyl ether synthase. Prostag Oth Lipid Mediat 68-69:457-470

Haluškova L, Valentovičová K, Huttová J, Mistrik I, Tamás L (2010) Effect of heavy metals on root growth and peroxidase activity in barley root tip. Acta Physiol Plant 32:59-65

Heath RL, Packer L (1968) Photoperoxidation in isolated chloroplasts. I. Kinetics and stoichiometry of fatty acid peroxidation. Arch Biochem Biophys 125:189-198

Howe GA, Schilmiller AL (2002) Oxylipin metabolism in response to stress. Curr Opin Plant Biol 5:230-236

Ishida A, Ookubu K, Ono K (1987) Formation of hydrogen peroxide by $\mathrm{NAD}(\mathrm{P}) \mathrm{H}$ oxidation with isolated cell wall-associated peroxidase from cultured liverwort cells Marchantia polymorpha L. Plant Cell Physiol 28:723-726

Kawano T (2003) Roles of the reactive oxygen species-generating peroxidase reactions in plant defence and growth induction. Plant Cell Rep 21:829-837

Kwak JM, Nguyen V, Schroeder JI (2006) The role of reactive oxygen species in hormonal response. Plant Physiol 141: 323-329

Lee SH, Lee MH, Chung WI, Liu JR (1998) WAPK, a Ser/Thr protein kinase gene of Nicotiana tabacum, is uniquely regulated by wounding, abscisic acid and methyl jasmonate. Mol Gen Genet 259:516-522

León J, Rojo E, Sánchez-Serrano JJ (2001) Wound signaling in plants. J Exp Bot 52:1-9

Lowry OH, Rosebrough NJ, Farr AL, Randall RJ (1951) Protein measurement with the Folin phenol reagent. J Biol Chem 193:265-275

Maksymiec W, Krupa Z (2002) The in vivo and in vitro influence of methyl jasmonate on oxidative processes in Arabidopsis thaliana leaves. Acta Physiol Plant 24:351-357

May MJ, Vernoux T, Leaver C, Van Montagu M, Inze D (1998) Glutathione homeostasis in plants: implications for environmental sensing and plant development. J Exp Bot 49(321):649-667

Mittler R, Vanderauwera S, Gollery M, Van Breusegem F (2004) Reactive oxygen gene network of plants. Trends Plant Sci 9:490-498

Nakano Y, Asada K (1981) Hydrogen peroxidase is scavended by ascorbate-specific peroxidase in spinach chloroplasts. Plant Cell Physiol 22:867-880

Ogawa K (2005) Glutathione-associated regulation of plant growth and stress responses. Antioxid Redox Sign 7:973-981

Parra-Lobato MC, Fernandez-Garcia N, Olmos E, Alvarez-Tinaut MC, Gómez-Jiménez MC (2009) Methyl jasmonate-induced antioxidant defence in root apoplast from sunflower seedlings. Environ Exp Bot 66:9-17

Pasternak TP, Prinsen E, Ayaydin F, Miskolczi P, Potters G, Asard H, van Onckelen HA, Dudits D, Feher A (2002) The role of auxin, $\mathrm{pH}$, and stress in the activation of embryogenic cell division in leaf protoplast-derived cells of Alfalfa. Plant Physiol 129: 1807-1819

Pietryczuk A, Piotrowska A, Czerpak R (2008) The influence of traumatic acid on the growth and metabolite content of the green alga Chlorella vulgaris Beijerinck. Oceanol Hydrobiol Stud 37(1):3-15

Piotrowska A, Bajguz A, Czerpak R, Kot K (2010) Changes in the growth, chemical composition, and antioxidant activity in the 
aquatic plant Wolffia arrhiza (L.) Wimm. (Lemnaceae) exposed to jasmonic acid. J Plant Growth Regul 29:53-62

Pirson A, Lorenzen H (1966) Synchronized dividing algae. Ann Rew Plant Physiol 17:439-458

Rice-Evans CA, Diplock AT, Symons MCR (1991) Techniques in free radical research. Elsevier, London

Sasaki-Sekimoto Y, Taki N, Obayashi T, Aono M, Matsumoto F, Sakurai N, Suzuki H, Hirai MY, Noji M, Saito K, Masuda T, Takamiya K, Shibata D, Ohta H (2005) Coordinated activation of metabolic pathways for antioxidants and defence compounds by jasmonates and their roles in stress tolerance in Arabidopsis. Plant J 44:653-668

Siedow JN (1991) Plant lipoxygenase: structure and function. Ann Rev Plant Physiol 42:145-188
Sivasankar S, Sheldrick B, Rothstein SJ (2000) Expression of allene oxide synthase determines defense gene activation in tomato. Plant Physiol 122:1335-1342

Szalai G, Kellös T, Galiba G, Koesu G (2009) Glutathione as an antioxidant and regulatory molecule in plants under abiotic stress conditions. J Plant Growth Regul 28:66-80

Szczegielniak J (2007) Wound signal transduction pathway in plants. Post Biochem 53:121-132

Zimmerman DC, Coudron CA (1979) Identification of traumatin, a wound hormone, as 12-oxo-trans-10-dodecenoic acid. Plant Physiol 63:536-541

Żuchowski J (1999) Vegetable superoxide dismutases. Kosmos 48: 87-93 